\title{
Identification of white spot syndrome associated baculovirus (WSBV) target organs in the shrimp Penaeus monodon by in situ hybridization
}

\author{
Poh-Shing Chang ${ }^{1}$, Chu-Fang Lo ${ }^{2}$, Yu-Chi Wang ${ }^{2}$, Guang-Hsiung Kou ${ }^{2, *}$ \\ ${ }^{1}$ Department of Aquaculture, National Kaohsiung Institute of Marine Technology, Kaohsiung, Taiwan, ROC \\ ${ }^{2}$ Department of Zoology, National Taiwan University, Taipei, Taiwan, ROC
}

\begin{abstract}
Penaeus monodon non-occluded baculovirus III (PmNOB III) is a strain of white spot syndrome associated baculovirus (WSBV) isolated from diseased black tiger shrimp P. monodon. In order to identify the target organs of WSBV, the tissue sections of experimentally infected shrimp sampled at $0,16,22,40,52$, and $64 \mathrm{~h}$ post-infection were hybridized in situ with PmNOB III DNAspecific probe labeled with digoxigenin. WSBV-positive cells were initially observed at $16 \mathrm{~h}$ postinfection in the stomach, gill, cuticular epidermis and hepatopancreas. At 22 h post-infection, the lymphoid organ, antennal gland, muscle tissue, hematopoietic tissue, heart. midgut and hindgut were found to be WSBV-positive. The nervous tissue and compound eyes did not have WSBV-positive cells until $40 \mathrm{~h}$ post-infection. Thus various tissues from the mesoderm and ectoderm, such as connective tissue, epithelium, nervous tissue and muscle, can all be infected by WSBV. By 52 or 64 h post-infection, it was found that the stomach, gill, cuticular epidermis, lymphoid organ, hematopoietic tissue and antennal gland were all hedrily infected with WSBV and that these tissues had become necrotic. The white spot syndrome itself first appeared at $40 \mathrm{~h}$ post-infection, and the shrimp began to die at $64 \mathrm{~h}$ post-infection. The probe demonstrated no reaction to WSBV-negative tissue.
\end{abstract}

KEY WORDS: PmNOB III WSBV In situ hybridization - White spot baculovirus Penaeid shrimp

\section{INTRODUCTION}

White spot syndrome associated non-occluded baculovirus (WSBV) is the causative agent of a shrimp viral disease. The affected individuals always show white spots on their exoskeleton and this is the principal sign of the disease (Chou et al. 1995, Wang et al. 1995). Based on the published description, WSBV is also apparently related to Japan's rod-shaped nuclear virus of Penaeus japonicus (RV-PJ; Inouye et al. 1994 Momoyama et al. 1994, Nakano et al. 1994, Takahashi et al. 1994), China's hypodermal hematopoietic necrosis baculovirus (HHNBV; Cai et al. 1995) and Thailand's systemic ectodermal and mesodermal baculovirus (SEMBV; Wongteerasupaya et al. 1995).

\footnotetext{
- Addressee for correspondence

E-mail: ghkou@ccms.ntu.edu.tw
}

WSBV is extremely virulent, has a wide host range and targets various tissues. The known hosts of WSBV include Penaeus japonicus, $P$. monodon, $P$. chinensis and P. penicillatus (Cai et al. 1995. Wang et al. 1995). According to a study by Momoyama et al. (1994) on the histopathology of RV-PJ-infected $P$. japonicus, degenerated cells with basophilic hypertrophied nuclei were observed in various tissues originating from both mesoderm and the ectoderm, such as the cuticular epidermis, connective tissue, lymphoid organ, antennal gland, hematopoietic tissue and nervous tissue (Momoyama et al. 1994). The virus can induce $100 \%$ mortality in infected shrimp within 3 to $5 \mathrm{~d}$ (Nakano et al. 1994). Since 1993 the virus has been a significant pathogen in cultured shrimp in Asia.

The virions of Penaeus monodon non-occluded baculovirus III (PmNOB III), which is a strain of WSBV isolated from diseased black tiger shrimp $P$. monodon, 
have been purified. In negatively stained preparations, the virion measures 70 to $150 \mathrm{~nm}$ at its broadest point and is 250 to $380 \mathrm{~nm}$ long, which is usually $10 \%$ larger than in ultrathin sections (Wang et al. 1995). A PmNOB III genomic DNA library was also constructed and a set of specific primers was designed for the polymerase chain reaction (PCR) to detect PmNOB III infection in penaeid shrimp (Lo et al. 1996). However, the sites of early viral infection and the stages of the progression of WSBV infection through the shrimp remained unknown.

This paper reports on the use of a PmNOB III DNAspecific probe to identify by in situ hybridization the target organs and tissues of WSBV in experimentally infected shrimp. With this technique, we could identify the major tissues which were sites of initial viral infection as well as the preferred attack sites of WSBV. We were also able to follow the stages of the progression of WSBV infection in shrimp. The results of our current studies will provide important insights into the pathogenic mechanism, early diagnosis and disease control.

\section{MATERIALS AND METHODS}

Experimental iniection. Samples of Penaeus monodon were obtained from a shrimp farm at Kaohsiung in Taiwan. They were originally determined to be not infected by PmNOB III by PCR detection. Detection of the virus by PCR followed the methods of Lo et al. (1996). Three groups of about 30 shrimps weighing 0.35 to $0.45 \mathrm{~g}$ were kept in 501 plastic tanks containing salinity 20 ppt, filtered, aerated sea water at ambient temperature (approximately 28 to $30^{\circ} \mathrm{C}$ ). Two of these groups were fed with severely PmNOB III-infected $P$. monodon for one meal and then with artificial diet for the subsequent days. The third group of shrimp served as a negative control and were fed with artificial diet throughout the study.

Sampling procedure and treatment. Three shrimp from each group were sampled at 0, 16, 22, 40, 52 and $64 \mathrm{~h}$ post-infection (pi). These shrimp were fixed in buffered neutral formalin solution $110 \%$ formalin $33 \mathrm{mM} \mathrm{NaH}_{2} \mathrm{PO}_{4}, 45 \mathrm{mM} \mathrm{Na} \mathrm{HPO}_{4}$ ). The fixed tissues were dehydrated, embedded in paraffin wax and sectioned at approximately 4 to $5 \mu \mathrm{m}$ thickness on a rotary microtome. The sections were stained with modified hematoxylin and eosin (H\&E stain) for normal histology and the sections from the same tissue blocks were also placed onto $2 \%$ silane pretreated slides for further in situ hybridization (Nuovo et al. 1991).

DNA probe for in situ hybridization. The recombinant plasmid pms 146 selected from the PmNOBUI Sal I genomic library (Lo et al. 1996) was used for the preparation of the DNA probe. The insert of pms 146 was gel purified and nonradioactively labeled with digoxigenin-dUTP using a random priming method available from Boehringer Mannheim Biochemical, Bedford, England.

In situ hybridization procedure. The tissue sections were deparaffinized in xylene and rehydrated by a series of graded alcohols (absolute to $50 \%$ ) and finally with distilled water The sections were soaked briefly in phosphate-buffered saline (PBS; $0.137 \mathrm{M} \mathrm{NaCl}$, $0.0027 \mathrm{M} \mathrm{KCl}, 0.0043 \mathrm{M} \mathrm{Na}_{2} \mathrm{HPO}_{4} \cdot 2 \mathrm{H}_{2} \mathrm{O}, 0.0014 \mathrm{M}$ $\mathrm{KH}_{2} \mathrm{PO}_{4}, \mathrm{pH} 7.4$ ) and then placed for $10 \mathrm{~min}$ in $0.02 \mathrm{~N}$ $\mathrm{HCl}$. After washing twice for $5 \mathrm{~min}$ in $\mathrm{PBS}$ at room temperature (RT), the slides were treated for $30 \mathrm{~min}$ with $100 \mu \mathrm{g} \mathrm{ml}^{-1}$ proteinase $\mathrm{K}$ in PBS at $37^{\circ} \mathrm{C}$. Following the proteolytic treatment, slides were washed twice for 5 min in PBS containing $0.2 \%$ glycine. Postfixation was carried out by $4 \%$ paraformaldehyde in PBS for 10 min at RT, and then the sections were washed in $0.2 \%$ glycine in PBS for 10 min followed by a wash in $2 \times$ standard saline citrate $\left(\mathrm{SSC}_{1} 1 \times \mathrm{SSC}=\right.$ $0.15 \mathrm{M} \mathrm{NaCl}, 0.015 \mathrm{M}$ tri-sodium citrate, $\mathrm{pH} 7.0$ ). These sections were pre-hybridized in $500 \mu$ hybridization solution (50\% formamide, $0.2 \%$ Ficoll $400,0.2 \%$ polyvinylpyr rolidone, $0.2 \%$ bovine serum albumin (BSA), $5 \times \mathrm{SSC}, 50 \mathrm{mM}$ Tris- $\mathrm{HCl}, \mathrm{pH} 8.0,1 \mathrm{mM}$ EDTA) for $1.5 \mathrm{~h}$ at $37^{\circ} \mathrm{C}$. Digoxigenin-labeled DNA probes were diluted to $10 \mathrm{ng} \mathrm{m}^{-1}$ in hybridization solution and 100 Hl was applied to each slide. A cover glass was put on top and the slides were placed on a $95^{\circ} \mathrm{C}$ hot plate for $5 \mathrm{~min}$. The slides were then transferred to a humid chamber and incubated at $37^{\circ} \mathrm{C}$ for 16 to $20 \mathrm{~h}$. After hybridization, the slides were uncovered and washed by $2 \times \mathrm{SSC}$ for 30 min at RT, followed by $1 \times \mathrm{SSC}$ for $30 \mathrm{~min}$ at RT, $0.5 \times \mathrm{SSC}$ for $30 \mathrm{~min}$ at $37^{\circ} \mathrm{C}$ and then $0.5 \times \mathrm{SSC}$ for $30 \mathrm{~min}$ at RT.

Hybridization detection. The slides were washed briefly in Buffer I (100 mM Tris- $\mathrm{HCl}, 150 \mathrm{mM} \mathrm{NaCl}$, $\mathrm{pH} 7.5$ ) and then blocked with Buffer I containing $1 \%$ blocking reagent (Boerhringer) (Buffer II) for $30 \mathrm{~min}$ at $37^{\circ} \mathrm{C}$. The alkaline phosphatase-conjugated antidigoxigenin was diluted 1:2500 in Buffer II. The slides were covered with $300 \mu$ diluted conjugate and incubated for $30 \mathrm{~min}$ at $37^{\circ} \mathrm{C}$ in a dark, humid chamber After washing twice for 15 min with Buffer I containing $0.3 \%$ Tween-20, the slides were equilibrated for $5 \mathrm{~min}$ in Buffer III (100 mM Tris- $\mathrm{HCl}, 100 \mathrm{mM} \mathrm{NaCl}, 50 \mathrm{mM}$ $\mathrm{MgCl}_{2}, \mathrm{pH}$ 9.5) at RT The slides were covered with $500 \mu \mathrm{l}$ of freshly prepared color developer [45 $\mu$ l nitroblue tetrazolium (90 mM) and 35 l 5-bromo-4-chloro3-indoyl phosphate $(120 \mathrm{mM})$ in $10 \mathrm{ml}$ Buffer III] and were then incubated for $1 \mathrm{~h}$ or overnight at RT After incubation, the slides were washed with $1 \times$ TE buffer for 5 min at RT. Neutral red was used to counterstain the slides for $10 \mathrm{~min}$ and then they were dehydrated with a series of graded alcohols ( $80 \%$ to absolute), 
before being finally immersed in xylene. Each slide was then mounted with a plastic lid by using a histological mounting medium and examined under an Olympus BX-50 bright field light microscope.

\section{RESULTS}

\section{Infectivity and mortality of the experimental infection}

The percentages of sampled shrimp with positive in situ hybridization are shown in Table 1 . At $16 \mathrm{~h} \mathrm{pi.}$ $33 \%$ of the shrimp showed a blue to purple precipitate in their tissues. At $22 \mathrm{~h} \mathrm{pi}, 66 \%$ of the shrimp produced a positive signal and by $40 \mathrm{~h}$ pi all the sampled shrimps were found to be WSBV-positive by the in situ hybridization method. These percentages were similar to those of shrimp found positive by PCR. The white spot syndrome itself was first seen in the shrimp sampled at $40 \mathrm{~h}$ pi. The size and number of white spots increased

Table 1. Detection of white spot syndrome associated non-occluded baculovirus in tissues of experımentally infected Penaeus monodon by in situ hybridization. pi: post-infection

\begin{tabular}{|c|c|c|c|c|c|c|}
\hline & 0 h pi & $16 \mathrm{~h} \mathrm{pi}$ & $22 \mathrm{~h} \mathrm{pi}$ & $40 \mathrm{~h} \mathrm{pi}$ & $52 \mathrm{~h} \mathrm{pi}$ & $64 \mathrm{~h} \mathrm{pi}$ \\
\hline In situ hybridization & $0 \%$ & $33 \%$ & $66 \%$ & $100 \%$ & $100 \%$ & $100 \%$ \\
\hline White spot syndrome ${ }^{b}$ & - & - & - & + & ++ & +++ \\
\hline Mortality ${ }^{c}$ & $0 / 30$ & $0 / 27$ & $0 / 24$ & $0 / 21$ & $0 / 18$ & $5 / 15$ \\
\hline \multicolumn{7}{|c|}{$\begin{array}{l}\text { "Percentage of positive shrimps in each sampled detected by in situ } \\
\text { hybridization } \\
\text { "Relative amount and size of white spots on the carapace: (-) no white } \\
\text { spot detected, }(+) \text { few and small, (++) many and small, (+++) many and large } \\
\text { "Mortality of remaining shrimps at each sampling }\end{array}$} \\
\hline
\end{tabular}

Table 2. Chronological appearance and staining intensity of white spot syndrome associated non-occluded baculovirus by in situ hybridization in tissues of experimentally infected Penaeus monodon. pi: post-infection. Relative intensity of positive staining and integrity of cell: $(+)$ light blue, intact cell with normal nuclei; $(++)$ bright blue, intact cell with hypertrophied nuclei; $(+++)$ blue to purple, cell with disintegrated nuclear membrane; $(++++)$ bright purple, cell lysed; $(-)$ no colored precipitate detected

\begin{tabular}{|lccccccc|}
\hline Tissue & $0 \mathrm{~h} \mathrm{pi}$ & $16 \mathrm{~h} \mathrm{pi}$ & $22 \mathrm{~h} \mathrm{pi}$ & $40 \mathrm{hpi}$ & $52 \mathrm{~h} \mathrm{pi}$ & $64 \mathrm{~h} \mathrm{pi}$ \\
\hline Stomach & - & + & ++ & +++ & ++++ & ++++ \\
Gill & - & + & ++ & ++ & +++ & ++++ \\
Cuticular epidermis & - & + & +++ & +++ & ++++ & ++++ \\
Hepatopancreas & - & + & + & + & ++ & ++ \\
Heart & - & - & + & ++ & ++ & +++ \\
Lymphoid organ & - & - & + & ++ & +++ & ++++ \\
Hematopoietic tissue & - & - & + & ++ & +++ & ++++ \\
Antennal gland & - & - & + & ++ & +++ & ++++ \\
Mid-and hindgut & - & - & + & + & ++ & +++ \\
Compound eye & - & - & - & + & ++ & ++ \\
Nervous system & - & - & - & + & ++ & ++ \\
\hline
\end{tabular}

subsequently with sampling time. No experimental shrimp died until $64 \mathrm{~h}$ pi, at which time the mortality of the remaining shrimp was $33 \%$. Shrimp in the control group did not show any positive signal in their tissues by in situ hybridization or by PCR, nor did they have any white spots on their carapaces. All the shrimp in e control group were healthy and survived during the experimental period (data not shown).

\section{Detection of WSBV by in situ hybridization}

The degree of WSBV infection in the tissues was ated by the number of cells with blue-purple precipitate, the intensity of coloration and the integrity of cells on a scale of + to ++++ . For those tissues that were intact and stained a light blue to purple in the nuclei, the ing of + was used. This corresponds to an early stage of infection. Intact tissues that were stained a bright blue and contained hypertrophied nuclei were given ratings of ++ . Tissues in which the nuclear membrane had disintegrated and blue to purple coloration extended to the cytoplasm were rated +++ . The tissues that were stained bright purple and showed obvious cytopathological changes were given a rating of ++++ . Intact tissues in which no pigmentation was detected were given a rating of -

The sequential progression of the virus to the organs is shown in Table 2. The light blue to purple precipitate was present in the nuclei of the columnar cuticular epithelial cells and spongy connective tissue of the stomach demonstrated at $16 \mathrm{~h}$ pi (Fig. 1A). These tissues were still intact and most of the cells did not show any cytopathological changes. The percentage of positive cells was not more than $10 \%$ at this time. At $22 \mathrm{~h}$ pi, the number of positive cells increased, the coloration turned deeper and hypertrophied cell nuclei began to appear (Fig. 1B). The degree of infection became more severe at $40 \mathrm{~h}$ pi (Fig. 1C). Even in the sections stained with $\mathrm{H} \& \mathrm{E}$, it was easy to observe the hypertrophied nuclei (Fig. 1E). Some cell nuclei were enlarged to more than twice the diameter of a normal nucleus. After $52 \mathrm{~h}$ pi, the epithelium layer and connective tissue of stomach were strongly positive and many cells were lysed (Fig. 1D). 


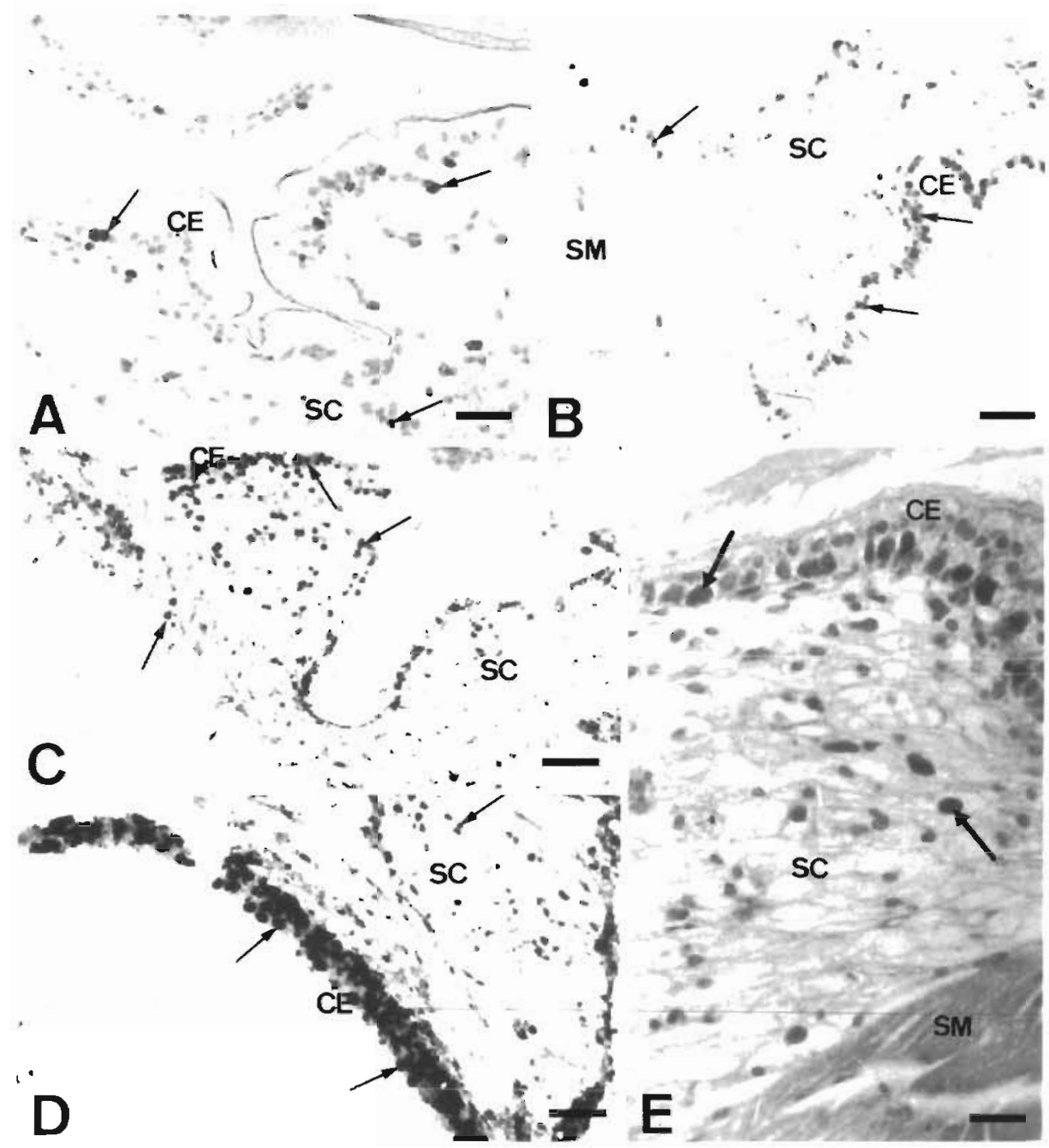

Fig. 1 Detection by in situ hybridization of white spot syndrome associated non-occluded baculovirus (WSBV) in the stomach of experimentally infected shrimp sampled at different times: (A) $16 \mathrm{~h}$ post-infection (pi), (B) $22 \mathrm{~h}$ pi, (C) $40 \mathrm{~h}$ pi, (D) $52 \mathrm{~h}$ pi. Positive cells (arrows) were located in the cuticular epithelium (CE) and spongy connective tissue (SC) but not in the smooth muscle layer (SM). Scale bar = $100 \mu \mathrm{m}$. (E) Severely affected epithelium in the stomach (H\&E stain; $40 \mathrm{~h}$ pi). The nuclei of the CE cells and the SC are hypertrophied (arrows). Scale bar = $50 \mu \mathrm{m}$

In the gill, viral DNA was first seen at $16 \mathrm{~h}$ pi in the epithelium of the primary and secondary filaments. The number of positive cells was small and the degree of infection was low initially (Fig. 2A). The color of the precipitate became deep blue and cytopathological changes began to occur at $52 \mathrm{~h}$ pi (Fig 2B). At $64 \mathrm{~h}$ pi, more than half of the epithelial cells were viruspositive, contained hypertrophied nuclei and had become degenerate. The organ structure was also disintegrated as the area of the lacunaes were increased (Fig. 2C). Cells with hypertrophied nuclei were observed in the sections stained with $\mathrm{H} \& \mathrm{E}$ at this time (Fig. 2D).

The cuticular epidermis (including the epithelium of the eye stalk, appendages and the epithelium under the carapace) were also first observed to have purple precipitate at $16 \mathrm{~h}$ pi. These epithelial cells became severely degenerative and lysed after $52 \mathrm{~h}$ pi (Fig. 3).

In the hepatopancreas, the connective tissues and myoepithelial cells of the hepatopancreas sheath and in the intertubular spaces were positive at $1.6 \mathrm{~h}$ pi but the epithelium of the tubules was not (Fig. 4A). Cyto- pathological changes in the hepatopancreas occurred at $40 \mathrm{~h}$ pi. After $52 \mathrm{~h}$ pi, most of the cells in the intertubular region were strongly positive but the tubular epithelium was still almost completely negative (Fig. 4B, C).

The virus was first seen in the heart, muscle tissue, lymphoid organ, hematopoietic tissue, antennal gland, midgut and hindgut at $22 \mathrm{~h}$ pi. In the heart, positive cells were located in muscle fibers and connective tissue. After $64 \mathrm{~h} \mathrm{pi}$ about $40 \%$ of the muscle fibers and connective tissue yielded a deep blue precipitate and contained hypertrophied nuclei (Fig. 5A.) In the muscle tissue, purple precipitate was present in the nuclei of the muscle fibers. At $64 \mathrm{~h}$ pi, the nuclei became hypertrophied and stained deep purple but the muscle fibers were still intact (Fig. 5B). In the lymphoid organ, many stromal matrix cells surrounding the lumen and the fibrous connective tissue were positive (Fig. 6A). These cells became lysed and the sheaths had degenerated by $64 \mathrm{~h}$ pi. The stem cells of the hematopoietic tissues were virus-positive (Fig. 6B). 
Fig. 2. Detection by in situ hybridization of WSBV in the gill of experimentally infected shrimp sampled at different times: (A) $16 \mathrm{~h}$ pi, (B) $52 \mathrm{~h} \mathrm{pi,} \mathrm{(C)} 64 \mathrm{~h}$ pi. Positive cells (arrows) were located in the epithelium of primary and secondary filaments. LA: lacunae (arrow head). Scale bar $=100 \mu \mathrm{m}$. (D) Severely affected epithelium in the gill ( $H \& E$ stain; $64 \mathrm{~h}$ pij. The nuclei of the epithelial cells (arrows) are hypertrophied. Scale bar = $50 \mu \mathrm{m}$

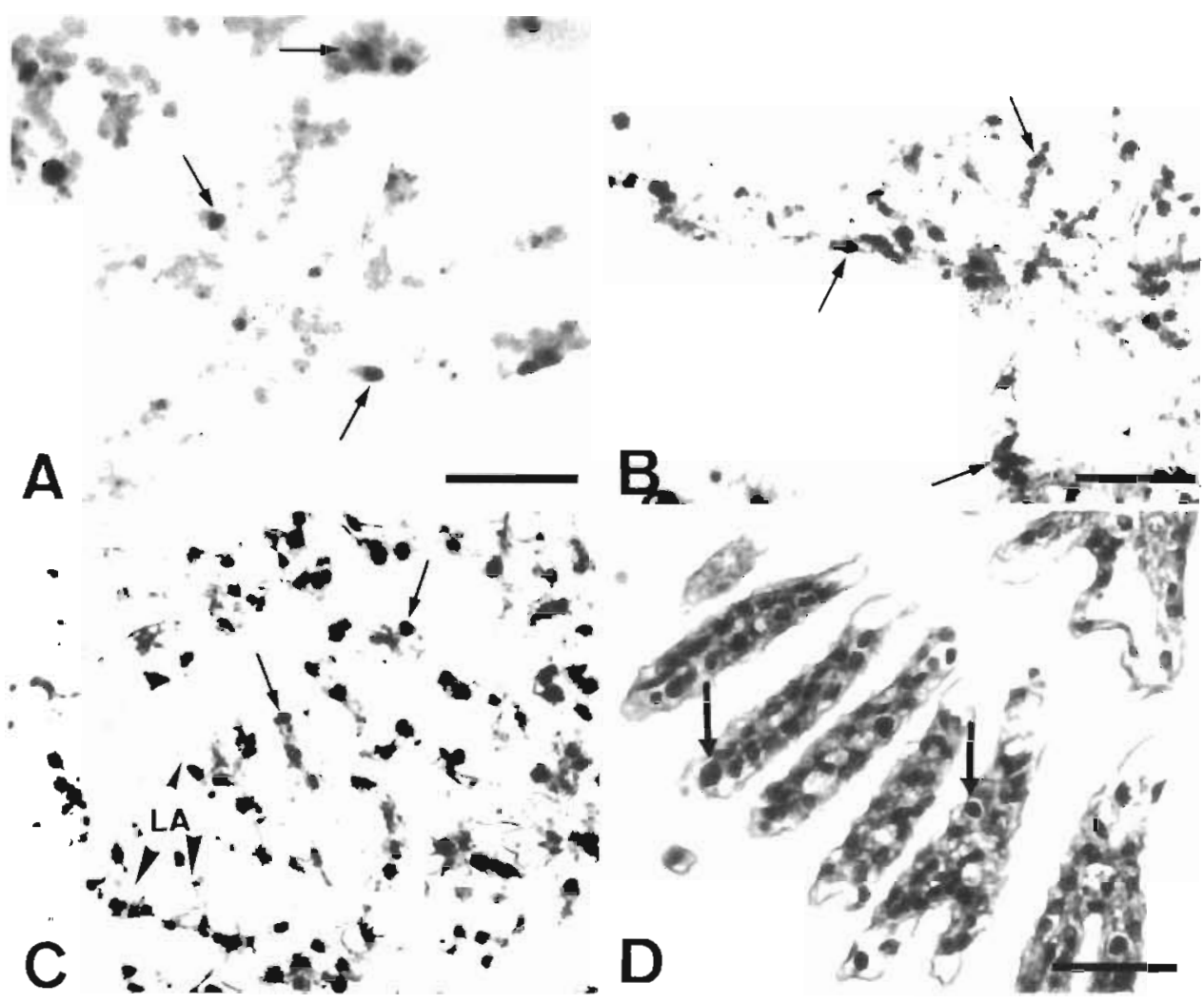

In the late infection stage, hematopoietic tissue was severely necrotic because most cells were lysed. In the antennal gland, the positive cells were located in the epithelium surrounding the gland tubules. The structure of the tubules disintegrated during the late infection stage (Fig. 6C). Unlike the stomach, the positive cells were located in the muscle and underlying connective tissue region but not in the epithelium of the midgut and hindgut. However, it is hard to determine whether the positive signal was in the muscle cells or in the connective tissue or both. At $64 \mathrm{~h} \mathrm{pi}$, the nuclei of positive cells became hypertrophied and stained deep purple (Fig. 6D).

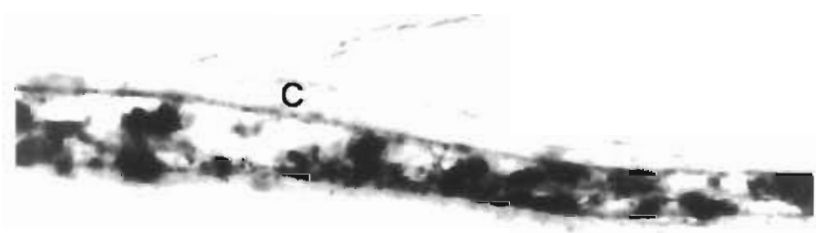

Fig. 3. Detection by in situ hybridization of WSBV in the pleopod of experimentally infected shrimp sampled at $52 \mathrm{~h}$ pi. Most of the epithelial cells were strongly positive and had hypertrophied nuclei. C: cuticle. Scale bar $=50 \mu \mathrm{m}$
The fasciculated zone and lamina ganglionaris of the compound eyes and the glial cells of the ganglia were initially viral DNA positive at $40 \mathrm{~h}$ pi. After $64 \mathrm{~h} \mathrm{pi}$, these tissues still showed only medium levels of infection (Fig. 7A, B).

\section{DISCUSSION}

The results demonstrated that a 1461 bp DNA fragment from the genomic library of PmNOB III can be used as a specific probe to detect WSBV in paraffinembedded, fixed tissues of infected shrimp by in situ hybridization. The absence of any precipitate in tissues not infected by WSBV suggests that this probe does not cross-react with shrimp tissue. Recently, in situ hybridization techniques have been developed for some shrimp virus diagnosis, such as infectious hypodermal and hematopoietic necrosis virus (IHHNV; Mari et al. 1993), Penaeus monodon-type baculovirus (MBV; Poulos et al. 1994), Baculovirus penaei (BP; Bruce et al. 1993) and hepatopancreatic parvo-like virus (HPV; Mari et al. 1995). The occluded baculovirus can be detected in the tissues of infected shrimp before the occlusion bodies occur by in situ hybridization (Bruce et al. 1994). It is more advantageous to use in situ hybridization to detect viral DNA in shrimp tissue than to use histological staining, electron microscopy or 


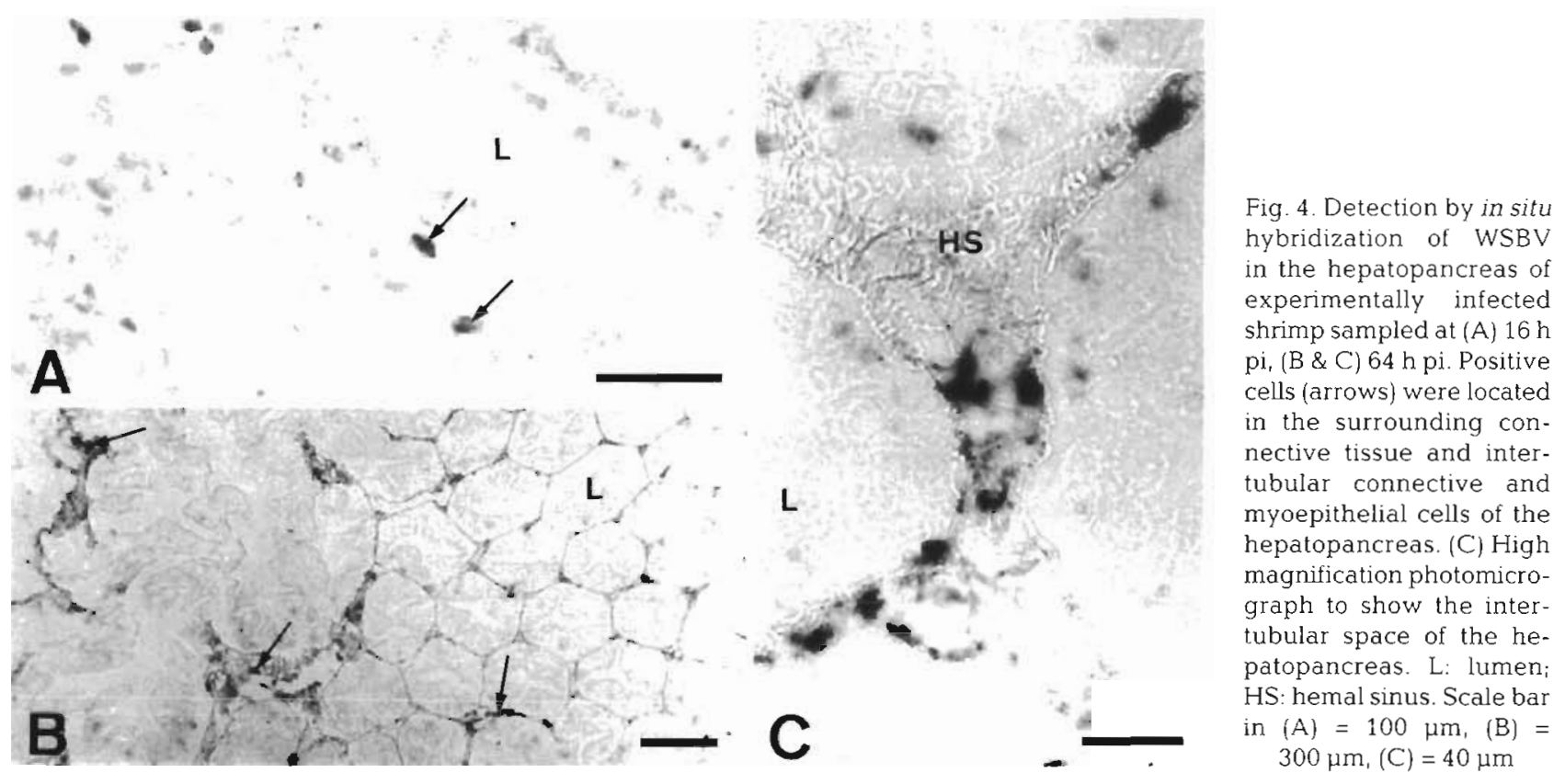

PCR. Although the electron microscopy technique can definitely provide the information about the sites of viral distribution and the state of viral maturation at the cellular level, much time is required to obtain the results and expensive equipment is also required. In situ hybridization can accurately provide the precise location of viral DNA present in tissue sections as a result of the highly specific interaction between the probe and the target sequence of viral DNA. This property makes in situ hybridization superior to PCR, which cannot provide information about the target cell type within a given organ or tissue. Although WSBV does not form occlusion bodies, it can be easily detected by histological staining in late stages of infection. However, this may be more difficult in the lightly infected stage when cytopathological phenomena are still not obvious. In situ hybridization can overcome this problem.
The results of this study suggest that the cuticular epithelium from every part of the body of the shrimp is one of the main target tissues for the WSBV. The connective tissues of some organs are also infected by WSBV In other tissues such as nervous tissue, muscle tissue, lymphoid tissue and hematopoietic tissue, WSBV DNA can also be observed. In terms of the organs, WSBV does severe damage to the stomach, gills, hematopoietic tissue, lymphoid organ, antennal gland and cuticular epidermis of the shrimp. During the late stages of infection, these organs were destroyed and many cells were lysed. The organs which were more lightly infected by WSBV included the hepatopancreas, nerve node, compound eye, the muscle and connective tissue of midgut and hindgut. The degree of infection of these organs did not increase and they maintained organ integrity up to the late infection stage, although a few cells had cyto-

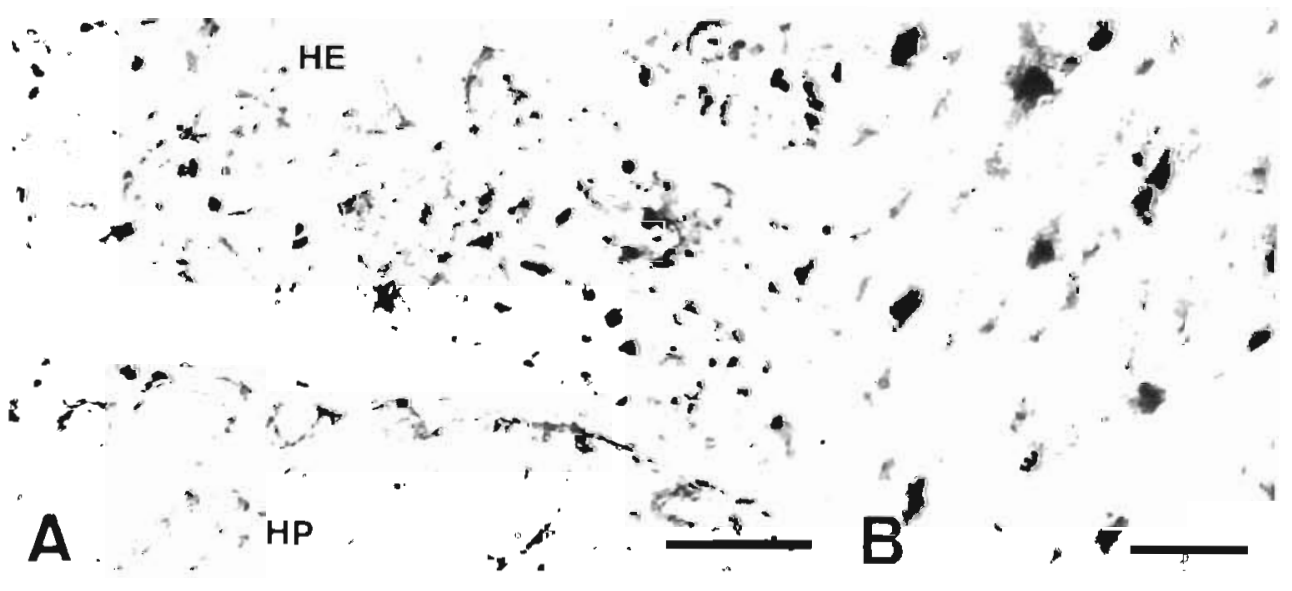

Fig. 5. Detection by in situ hybridization of WSBV in (A) the heart and (B) the muscle tissue of experimentally infected shrimp at $64 \mathrm{~h}$ pi Nuclet of muscle cells show a positive signal. HE: heart; HP: hepatopancreas. Scale bar in $(\mathrm{A})=$ $200 \mu \mathrm{m},(B)=50 \mu \mathrm{m}$ 
Fig. 6. Detection by in situ hybridization of WSBV in $(A)$ the lymphoid organ, (B) the hematopoietic tissue. (C) the antennal gland, and (D) midgut of experimentally infected shrimp sampled at $(A, B, C) 52 \mathrm{~h} p$ and at (D) $64 \mathrm{~h}$ pi. Positive cells indicated by arrows. FC: fibrous connective tissue; E: epithelium; L: antennel gland lumen; LM: midgut lumen MS: muscle; $S$ : stromal matrix cell Scale bar in (A) \& $(B)=50 \mu \mathrm{m}$, in (C) $=25 \mu \mathrm{m}$, in (D) $=100 \mu \mathrm{m}$

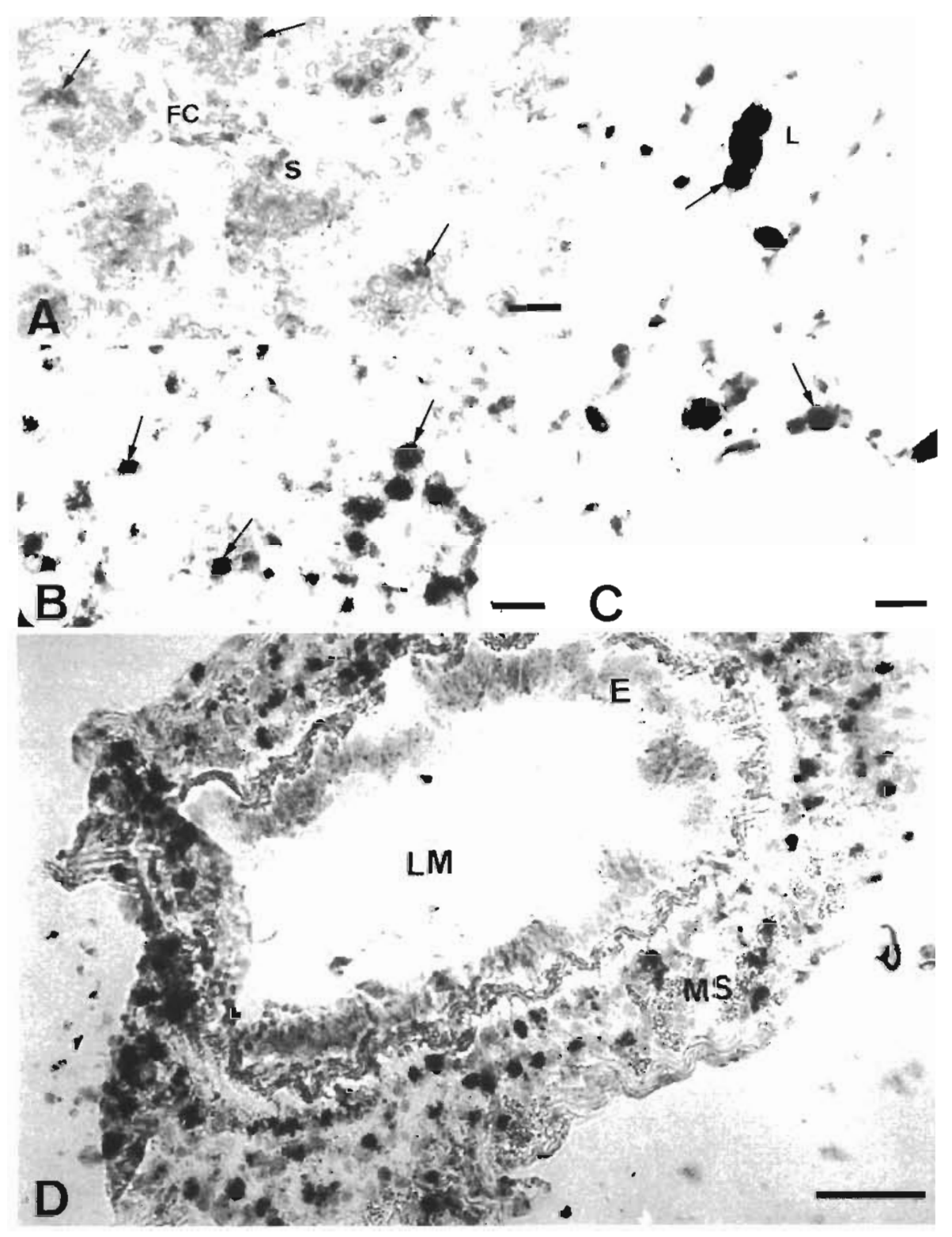

Fig. 7. Detection by in situ hybridization of WSBV in nervous tissues of experimentally infected shrimp sampled at $64 \mathrm{~h}$ pi. (A) compound eye. The positive cells (arrows) were located in the fasciculated zone $(F)$ and lamina ganglionaris (LG). CR: crystalline tract. Scale bar = $100 \mu \mathrm{m}$. (B) Ganglion. The glial cells of ganglion were positive (arrows). Scale $\mathrm{bar}=100 \mu \mathrm{m}$

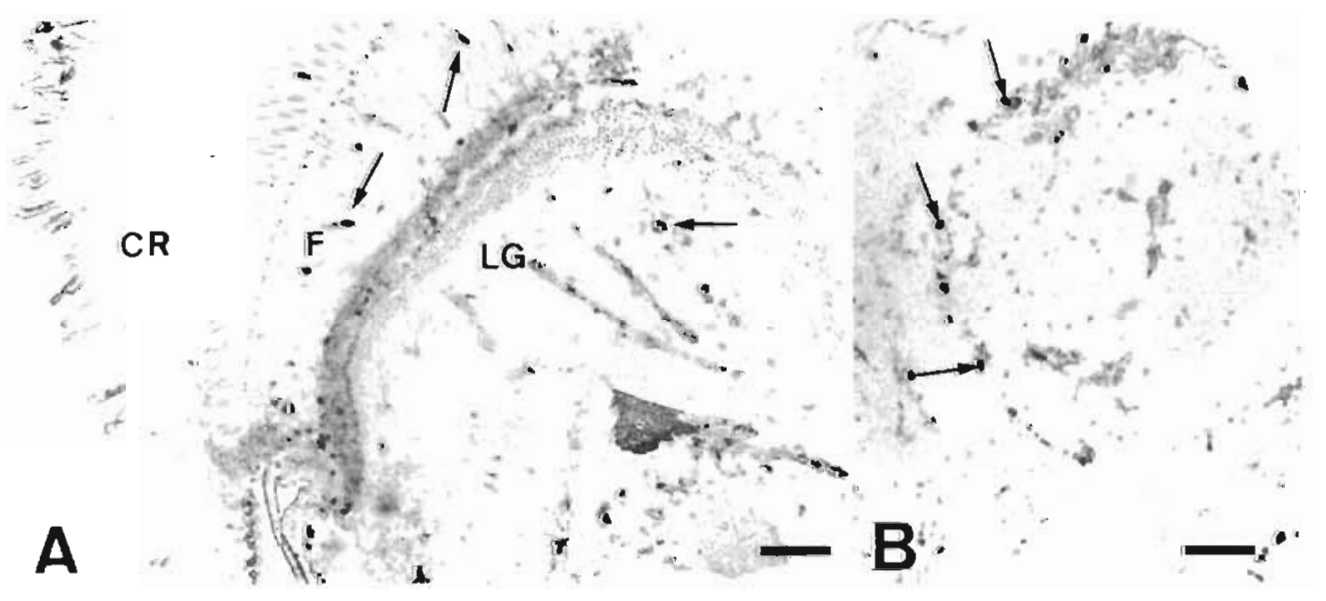


pathological signs and were lysed. Thus, it can be concluded that WSBV can infect shrimp tissues that originate from the ectoderm or the mesoderm. This distinguishes WSBV from other shrimp baculoviruses such as MBV, BP and baculoviral midgut gland necrosis virus (BMNV) which only infect the epithelial cells of the hepatopancreas tubules and the midgut in shrimp (Momoyama 1983, Chang et al. 1992, 1993, Bruce et al. 1993, 1994).

According to the results of this study, although WSBV can also infect the hepatopancreas, it is mainly confined to the myoepithelial cells of the hepatopancreatic sheath and the fibroblasts of the connective tissue; there was little evidence, if any, that it infected the epithelium of the tubules. Some parts of the hepatopancreas were lysed in the late infection stage but no viruses were detected. This lysis was evidently not due directly to virus infection, but was probably due to the generally unhealthy state of the infected shrimp and resulted from autolysis. As for the enteric tissue, the time at which midgut and hindgut were first detected to be infected with WSBV was later than for the stomach and the degree of infection was also lighter than the degree of infection in the stomach.

The results also show that the virus initially appears in the shrimp in the stomach, gill, cuticular epidermis and connective tissue of the hepatopancreas. Chou et al. (1995) indicated that under experimental. conditions the virus can infect the shrimp via water and oral inoculation. From this study, some shrimp sampled at $16 \mathrm{~h}$ showed virus in the stomach but not in the gills, while others sampled at the same time showed virus in the gills but not in the stomach (data not shown). This suggested that the virus infection could be either via the oral pathway or via water to the gill or cuticular epidermis. Since virus-infected shrimp tissues were given to the experimental shrimp as feed, both oral and waterborne infections were possible. In some sections, a few positive signals could be detected in the lumen of the stomach at the immediate onset of infection. Specifically, these signals were in the cuticle layer above the epithelium. This finding can be explained if the viruscontaining feed had just entered the stomach lumen and some of it had adhered to the setal grooves of the cuticle layer. It may also result from a non-specific binding to chitin that has been noted by Lightner (1996).

WSBV can also infect the heart, eyes and nervous tissue of shrimp. The most severely infected site of the eyes was the cuticular epidermis of the eye stalk. Some nerve cells of the compound eyes and glial cells of the ganglia were also lightly infected by WSBV in the late stage. Changes found in WSBV-infected shrimps can be distinguished easily from the white eye syndrome in Taiwan in 1991 in terms of brown fibrous nodules in the fasciculated zone of the compound eyes (Chen et al. 1991).
In conclusion, a sensitive, specific and nonradioactive nucleic acid probe can be used for the in situ detection of the WSBV genome. Viral infection was detected at an early stage, the degree of infection was determined, and target tissues were identified. The route of WSBV entry and progression of the disease caused by WSBV was also established.

Acknowledgements. This work was supported by the National Science Council under grant NSC 85-2321-B-022001 and the Council of Agriculture under grant No. 85-AST1.1-FAD-49(21)A.

\section{LITERATURE CITED}

Bruce LD, Lightner DV, Redman RM (1994) Comparison of traditional and molecular detection methods for baculovirus penaei infections in larval Penaeus vannamei. I Aquat Anim Health 6:355-359

Bruce LD, Redman RM, Lightner DV, Bonami JR (1993) Application of gene probes to detect a penaeid shrimp baculovirus in fixed tissue using in situ hybridization. Dis Aquat Org 17:21.5-221

Cai S, Huang J, Wang $C$, Song X, Sun X, Yu J, Zhang Y, Yang $C$ (1995) Epidemiological studies on the explosive epidemic disease of prawn in 1993-1994. J Fish China 19: $112-117$

Chang PS, Lo CF, Kou GH., Lu CC, Chen SN (1993) Purification and amplification of DNA from Penaeus monodontype baculovirus (MBV). J Invertebr Pathol 62:116-120

Chang PS, Wang YC, Lo CF, Kou GH, Chen SN (1992) Purification and biochemical characteristics of occlusion body of Penaeus monodon-type baculovirus (MBV). Fish Pathol $27: 1.27-130$

Chen SN, Chang PS, Kou GS (1991) Surveys on the diseases of cultured Penaeus japonicus in Taiwan. Environmental survey and its improvement on shrimp grow-out pond. COA. (Counc Agric) Fish Ser 28:123-132

Chou HY, Huang CY, Wang CH, Chiang HC, Lo CF (1995) Pathogenicity of a baculovirus infection causing white spot syndrome in cultured penaeid shrimp in Taiwan. Dis Aquat Org 23:165-173

Inouye K, Miwa S, Oseko N, Nakano H, Kimura T (1994) Mass mortalities of cultured kuruma shrimp, Penaeus japonicus. in Japan in 1993: electron microscopic evidence of the causative virus. Fish Pathol 29:149-158 (In Japanese)

Lightner (1996) A handbook of pathology and diagnostic procedures for diseases of penaeid shrimp. World Aquaculture Society, Baton Rouge, LA

Lo $\mathrm{CF}$, Leu JH, Ho CH, Chen $\mathrm{CH}$, Peng SE, Chen YT, Chou CM, Yeh PY, Huang CJ, Chou HY, Wang CH, Kou GH (1996) Detection of baculovirus associated with white spot syndrome (WSBV) in penaeid shrimps using polymerase chain reaction. Dis Aquat Org 25:133-141

Mari J, Bonami JR, Lightner DV (1993) Partial cloning of the genome of infectious hypodermal and hematopoietic necrosis virus, an unusual parvovirus pathogenic for penaeid shrimps: diagnosis of the disease using a specific probe. J Gen Virol 74:2637-2643

Mari J, Lightner DV, Poulos BT, Bomani JR (1995) Partial cloning of the genome of an unusual shrimp parvovirus (HPV): use of gene probes in disease diagnosis. Dis Aquat Org 22:129-134 
Momoyama K (1983) Studies on baculoviral mid-gut gland necrosis of kuruma shrimp (Penaeus japonicus) III. Fish Pathol 17:263-268

Momoyama K, Hiraoka M, Nakano $H$, Koube $H$, Inouye $K$, Oseka N (1994) Mass mortalities of cultured kuruma shrimp, Penaeus japonicus, in Japan in 1993: histopathological study. Fish Pathol 29:141-148 (in Japanese)

Nakano H. Koube H, Umezaea S, Momoyama K. Hiraoka M, Inouye K, Oseko N (1994) Mass mortalities of cultured kuruma shrimp, Penaeus japonicus, un Japan in 1993: epizootiological survey and infection trials. Fish Pathol 29: 135-139 (un Japanese)

Nuovo GJ, Darfler MM, Imparaim CC, Bromley SE (1991) Occurrence of multiple types of human papillomavirus in genital tract lesions: analysis by in situ hybridization and the polymerase chain reaction. Am J Pathol 58: $518-523$

Poulos BT, Mari J, Bonami JR, Redman R, Lightner DV (1994) Use of non-radioactively labeled DNA probes for the

Responsible Subject Editor: J. E. Stewart, Dartmouth, Nova Scotia, Canada detection of a baculovirus from Penaeus monodon (PmSNPV $=$ MBV) by in situ hybridization on fixed tissue. J Virol Meth 49:187-194

Takahashi Y, Itami T, Kondom M, Maeda M, Fujii R, Tomonaga $S$, Supamattaya K, Boonyaratpalın $S$ (1994) Electron microscopic evidence of bacilliform virus infection in Kuruma shrimp (Penaeus japonicus). Fish Pathol 29: $121-125$

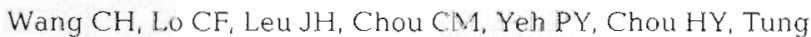
MC, Chang CF, Su MS, Kou GH (1995) Purification and genomic analysis of baculovirus associated with white spot syndrome (WSBV) of Pendeus monodon. Dis Aquat Org 23:239-242

Wongteerasupaya C, Vickers JE, Sriurairatana S, Nash GL, Akarajamorn A, Boonsaeng V, Panyim S, Tassanakajon A, Withyachumnarnkul B, Flegel TW (1995) A non-occluded, systemic baculovirus that occurs in cells of ectodermal and mesodermal origin and causes high mortality in the black tiger prawn Penaeus monodon. Dis Aquat Org 21:69-77

Manuscript first received: January 24, 1996

Revised version accepted: May 2, 1996 